\title{
Editorial
}

\section{La UCA en su cuadragésimo aniversario}

La Universidad Centroamericana "José Simeón Cañas" (UCA) cumplió cuarenta años. No fueron necesarios grandes fastos ni un costoso despliegue mediático para tener presente esa efeméride. Lejos de ello, la UCA ba preferido reflexionar sobre su compromiso con la sociedad salvadoreña y sobre la modalidad que este compromiso debe tomar en la realidad actual.

El compromiso de la UCA es, ante cualquier cosa, universitario. El rector mártir, Ignacio Ellacuría, defendía la idea de que el compromiso social no desviara a la universidad de su identidad académica. Frente a posturas simplistas, que demandaban un activismo irreflexivo, Ellacuría privilegió el papel crítico y cuestionador del poder que la universidad puede y debe desempeñar.

Durante los años que abarcan la década de los setenta y los primeros años de los noventa - que marcan el inicio, la escalada y el desenlace del conflicto armado-, la UCA se comprometió con los cambios políticos necesarios en el país. La Universidad comprendio que las grandes mayorias del país vivían en carne propia los efectos de las injusticias estructurales y por ello puso todas sus 
energías para contribuir a la erradicación de las mismas. Pero no a través de la violencia, no a través de un derramamiento de sangre cuya principal victima sería el pueblo. Por eso, una y otra vez -durante la fracasada reforma agraria de Molina; durante la escalada de la represión y la violencia armada, durante los dias del golpe de Estado de 1979 y durante la acelerada polarización del país que dio lugar a una guerra de doce años- la UCA insistió en la necesidad de hacer cambios sociales, económicos y políticos. Instó a los dueños del poder a renunciar a sus excesivos privilegios, para darles a esas mayorias populares un modo de vida digno. Instó, además, a todos los sectores del país, a que optaran por el diálogo para resolver los conflictos, en vez de recurrir a la violencia y al exterminio del adversario. Para quienes veían las cosas en términos simplistas, la escalada de la violencia demostró que las soluciones racionales eran imposibles. Pero, a la vuelta de algunos años, la realidad les demostró que las soluciones violentas eran inviables bajo cualquier punto de vista. Ni un bando ni el otro pudieron ganar el conflicto militarmente. La UCA se comprometió en dar su aporte universitario para la solución negociada de la guerra, propugnando el protagonismo de aquellos sectores de la sociedad salvadoreña que escapaban al esquema polarizado de los bandos en pugna y que querian la paz para El Salvador, es decir, la llamada "tercera fuerza".

En la posguerra, las urgencias del pais eran otras. La UCA, que se habia comprometido en la buisqueda de la paz, habia pagado el precio de esta paz: Seis de sus más prominentes intelectuales, entre ellos, el rector Ellacuria, y dos empleadas suyas, fueron asesinados por un batallón élite del ejército, en 1989. En 1992, el país y la UCA eran distintos. La UCA cambió su perfil político, acentuado en los ochenta por las urgencias del país, y cultivo más su perfil académico. Y no es que en el tiempo de la guerra la UCA descuidara la academia por la polis; al contrario, la UCA era reconocida en el país y en el extranjero por su solidez académica. La UCA de la posguerra realizó mucbos proyectos académicos que anteriormente no pudo realizar, dado el clima de violencia política del país. Por 
ejemplo, pasó de ser una universidad de grados a una universidad de postgrados. Un doctorado y varias maestrias en diversas especialidades, con catedráticos de nivel internacional, le dan una nueva proyección a la universidad. Esto no convierte a la UCA en una universidad elitista, sino que acentúa su compromiso en preparar mejores profesionales para el pais. En la medida en que una universidad salvadoreña logra ofrecer mayores espacios de formación profesional, de esta forma se eleva el nivel académico del país. Por otro lado, la UCA ba profundizado en sus investigaciones académicas sobre distintos temas de actualidad: Las emigraciones, las maras, las elecciones, son algunos ejemplos de ello.

En todo caso, hay algo que permanece a través de los años. La nota distintiva de la UCA es su compromiso con la realidad nacional. Esta es, como dijo Ellacuría, su principal cátedra. Alrededor de ella se vertebra el quehacer universitario, un quebacer que, a lo largo de estas cuatro décadas, procura estar a la altura de los tiempos. 